\title{
Conception of family members of people with mental disorders on self-help groups
}

\author{
Concepção de familiares de pessoas com \\ transtorno mental sobre os grupos de autoajuda \\ Grupo de autoayuda de la familia y la persona con \\ trastorno mental: la concepción de la familia
}

\author{
Adriano Brischiliaria \\ Jacqueline Botura Bessa ${ }^{b}$ \\ Maria Angélica Pagliarini Waidmanc \\ Sonia Silva Marcon ${ }^{d}$
}

DOl: $\quad$ http://dx.doi.org/10.1590/19831447.2014.03.41015

\footnotetext{
a Nurse. Doctoral degree student of Nursing of the Graduate Nursing Programme (PSE) at the Universidade Estadual de Maringá (UEM). Member of the Nucleus of Studies, Research, Assistance and Family Support (NEPAAF). Assistant Professor of the Department of Nursing at the UEM. Maringá - PR - Brazil.

${ }^{b}$ Nurse of the Family Health Programme of Maringá. Master's in Nursing from the Graduate Nursing Programme of the Universidade Estadual de Maringa (PSE/UEM). Maringá - PR - Brazil.

c In Memorian. Nurse. PhD in Philospophy of Nursing. Former Professor of the Graduate/Master's/Doctora Programme in Nursing of the Universidade Estadua de Maringá (PSE/UEM). Member of the NEPAAF.

d Nurse. PhD in Nursing. Professor of the Graduate Master's/Doctoral Programme in Nursing of the Universidade Estadual de Maringá (PSE/UEM). Coordinator of the Nucleus of Studies, Research, Assistance and Family Support (NEPAAF)
}

\section{ABSTRACT}

The aim of this study was to understand how family members of people with mental disorders conceive the performance of selfhelp groups (SG). This qualitative study was conducted with eleven family members who participate in a SG of the Maringaense Mental Health Association. Data were collected from April to June 2010 during group meetings, in an adjoining room, by means of semi-structured interviews, which were then subjected to content analysis. Two categories emerged: "The group compensates for deficiencies in care", which points out deficiencies arising from the formal care services and the benefits of $\mathrm{SG}$ for family members and, "Idealized care", which reveals the expectations of the family in relation to mental health care. It was concluded that family members would like activities of the $S G$ to be incorporated by mental health care services and for family care to become a part of the care plan. Descriptors: Nursing. Family. Mental health. Self-help groups.

\section{RESUMO}

0 objetivo foi compreender como os familiares de pessoas com transtorno mental concebem a atuação do grupo de autoajuda (GA). Estudo de abordagem qualitativa realizado com onze familiares participantes de um GA da Associação Maringaense de Saúde Mental. Os dados foram coletados no período de abril a junho de 2010, durante as reuniões do grupo, em sala anexa, por meio de entrevistas semiestruturadas e, em seguida, submetidos à análise de conteúdo. Emergiram duas categorias: "0 grupo supre deficiências da assistência", que aponta as lacunas dos serviços formais de assistência e os benefícios do GA para os familiares; e "0 cuidado idealizado", que revela a expectativa dos familiares em relação à atenção em saúde mental. Conclui-se que os familiares almejam que as atividades desenvolvidas pelo GA sejam incorporadas pelos serviços de assistência em saúde mental e que o cuidado à família passe a integrar o plano de assistência.

Descritores: Enfermagem. Família. Saúde mental. Grupos de autoajuda.

\section{RESUMEN}

El objetivo fue comprender cómo los familiares de las personas con trastorno mental conciben el desempeño del grupo de autoayuda (GA). Estudio de enfoque cualitativo consumado con once familias participantes en un GA de Asociación Maringaense de Salud Mental. Los datos fueron recogidos entre abril y junio de 2010, durante las reuniones del grupo en sala anexa, a través de entrevistas semiestructuradas y más sometidos a análisis de contenido. Emergieron dos categorías: "El grupo cumple deficiencias de la atención", que señala las deficiencias derivadas de los servicios de atención formales y beneficios de GA para los familiares y, "El cuidado idealizado", que revela las expectativas de la familia en relación con la atención de salud en salud mental. Se concluye que la familia tiene como objetivo las actividades desarrolladas por el GA se incorporan los servicios de atención en salud mental y la de atención a la familia se convierte en parte del plan de atención.

Descriptores: Enfermería. Familia. Salud mental. Grupos de autoayuda. 


\section{口INTRODUCTION}

As a result of changes in mental health care in recent decades, the families of people with mental disorders, previously excluded from the care provided for their family member, are currently important protagonists of care, considering that many individuals treated in closed institutions now live at home with their family members and carers on a daily basis (1).

Consequently, it is necessary to promote the inclusion of family members in mental health care, but in order to do this, health professionals must be adequately prepared, even to acknowledge the importance of family members when providing care for these patients ${ }^{(2)}$. Implementing care in mental health is a challenge, considering that there are not enough specialized services to efficiently support the demand for care in this area ${ }^{(2-3)}$. The delay in scheduling a psychiatric consultation denounces this situation.

In spite of the importance of the role of family members in care established in the psychiatric reform, families do not always have access to enough information and do not get the necessary support for care. This reveals the need to develop and implement new care practices and the effective establishment of networking ${ }^{(4)}$.

The mental health policy in force in Brazil is based on the deinstitutionalization and strengthening of the psychosocial care network (RAPS) $)^{(5)}$. The key points of out-of-hospital care, substitutes of psychiatric hospitalization, are: In-Home Therapy Services (IHT); Primary Healthcare Unit (UBS); Primary Care Teams; Mobile Consulting Rooms and Teams; Community Centre; Family Health Support Centre (NASF); Psychosocial Care Centre (CAPS) $)^{(5)}$. This policy establishes the consonance and partnership with the National Primary Care Policy and the appraisal of knowledge and specificities of the family ${ }^{(4)}$.

In this context, and with the purpose of jointly finding solutions to collective problems, self-help or support groups are created to help the family members of people with mental disorders, based on the difficulties that arise on a daily basis due to living with the disease and to their need for information and guidelines ${ }^{(6)}$.

They are a complement to the services offered and established by the RAPS, as they constitute a space where people can be helped to face change, crises, or even to adapt to new situations ${ }^{(6)}$. Generally, they are intended for meetings with individuals with similar problems, eager to develop a cohesive and supportive process ${ }^{(7)}$. The preventive potential of these groups comes from the possibility of people who are in similar situations ${ }^{(8)}$ to share their knowledge and experiences ${ }^{(9)}$.
In light of this reality and the needs that arise during the daily routines of mental health services, especially at the out-of-hospital care units, exposed as a result of faults in the effective rendering of the RAPS, and considering the historical moment through which mental health care is passing in Brazil ${ }^{(10)}$, the following question emerges: How do family members experience the support offered by self-help groups (SG). To answer this question, and considering that self-help group are an important strategy for effectively providing care in consonance with the objectives of the deinstitutionalization policy, the aim of this study was to understand how the family members of people with mental disorders conceive the performance of self-help groups.

\section{METHODOLOGY}

This descriptive, qualitative study was conducted in Maringá-PR with eleven families of people with mental disorders who frequented one of the self-help groups of the Associação Maringaense de Saúde Mental (AMSM) - a philanthropic mental health association that aims to promoted improvements in care and treatment of people with mental suffering and provide guidelines and support for their family members. It also aims to minimize bias, stigma and exclusion, ensure human and civil rights and prevent unnecessary internments. This association is voluntarily coordinated by mental health care professionals and the family members of patients. It is also respected by different sectors involved with mental health in the municipality, and has a representative in the municipal health council.

For data collection, five self-help groups operating in different regions of the city and three social inclusion and income generation projects operating in the association's main building were selected. Group meetings were held weekly, during which members discussed several aspects of mental disorders, according to demands of the participants, for 90 minutes. The groups are open to everyone and generally gathered in church halls in the evening. In addition to family members and sufferers, scholars of various healthcare programmes participated in the meetings, especially in the fields of nursing and psychology.

Data were collected from April to June 2010 by means of semi-structured interviews, which were recorded and subsequently fully transcribed. Interview were, on average, 50 minutes long, held on meeting days in an adjoining room. Only family members of people with schizophrenia and bipolar affective disorder were selected, as theses disorders are more serious and demand greater attention. 
These family members were invited to participate in the study when they attended the meetings and, if they agreed, were asked whether they preferred to have the interview during or after the meeting.

The statements were subjected to thematic content analysis based on the three proposed stages ${ }^{(11)}$. The transcripts were successively read and the parts of interest were highlighted, after which data were organized into categories. The final step was coding and inference based on the collected data ${ }^{(11)}$.

This study complied with the precepts of Resolution 466/2012 of the National Health Council and its project was approved by the Ethics Committee of the signatory institution (Decision 218/2009). All participants signed two copies of an informed consent statement. To protect their identities, the names of flowers were used to distinguish families, and the position of the member in relation to the patient.

\section{QRESULTS AND DISCUSSION}

Participants of the study were three mothers, two fathers, three sisters, one son, one grandfather and one grandmother who have lived with sufferers of a mental disorder from 3 to 16 years and have participated in the AMSM from 1 to 5 years, being that Acacia-father was one of its creators.

After successive readings of the statements, two thematic categories emerged, which are described below.

\section{The group compensates for deficiencies in care}

This category reveals the deficiencies in care provided at the different assistance points that form the RAPS and the benefits of support groups for family members. Normally, once a mental disorder is diagnosed, the patient is prescribed psychotropic medication and regular therapy is recommended. This, however, is evaluated by family members as being below their expectations of a medical consultation, as family members are not correctly oriented on how to relate to the sufferer, and access to more information on the disease is chiefly the result of an isolated search and not of the support of a formal mental health system.

[...] Only the people at the association give us any orientations, the only place where that is done is at the association, if you discover it even exists, that is. You consult a doctor and he never says, "Look, there's this association in such-and-such a place, go there and they'll give you some guidelines", there's none of that! That work doesn't exist. (Margarita-sister)

[...] We only found about this place at the church, after mass. (Fuchsia-grandmother)

There must be lots of cases of mental disorders, but not that many people come to the association. (Acacia-father)

These statements show that, in addition to professionals not correctly orienting family members on the disease, they do not indicate locations where these orientations can be obtained. Acacia-father, for example, realized that the low number of frequenters at the SG is the result of a lack of communication between the services of the mental health network and between healthcare professionals and the families. Generally, the existence of these groups is advertised in local churches or on posters at the Primary Care Units, showing that emphasis on drug treatment still prevails, with little interest and information on substitute services.

This was also observed in integrative revision study ${ }^{(10)}$ on nursing practices for people with schizophrenia. In general, doctors that work in Primary Care do not feel qualified enough to adequately deal with mental health cases, and even recognize the limitation of diagnosing and, consequently, prescribing psychotropic drugs and/or make adjustments to treatment ${ }^{(12)}$. In this context, the AMSM emerges as a location were family members find support to take better care of sufferers.

[...] "there isn't much I can do, I prescribe the medication, but he has to help himself. I am only here to medicate, there is not much more I can do". That was the doctor's answer. I got so mad with her for saying that! They have to assist the family. I don't know if they don't make enough money and think they don't have to do much for us, or if they just don't respect us. (Dahlia-mother)

When family members do not find the support they need to adequately deal with the situations that result from the disorder at the healthcare services, they seek help at the SG, that tries to compensate for the deficiencies of the RAPS services. These deficiencies are the results of high demand, but also of the attitude of some professionals, as shown in the statements of Dahlia-mother.

The absence of a care network for families jeopardizes the care provided to sufferers of mental disorders, the families involved in care and the family as a whole. In fact, the lack of appropriate space where they can 
discuss and reflect on their everyday lives with these sufferers prevents family members from perceiving the possibility of improvement or alternatives to ensure autonomy of the sufferer. This eventually creates an even greater burden, especially for those who are directly involved with the daily routines, and forces them to point out strategies that can help them deal with aspects related to the disorder.

[...] At the association, as they are already doing, or professionals of the health secretariat, should gather family members and provide targeted training. Then the person with the mental disorder becomes aware of the problem. (Acacia-father)

The lack of training of family members and carers in relation to crisis management, and the importance of groups such as those of the AMSM has been pointed out in another study ${ }^{(13)}$. It is true that these periodic and programmed health education groups or open psycho-educational groups that provide training on mental health can provide these families with appropriate information on the disease, prognosis and management, and a space for them to express their feelings resulting from the subjective and objective incumbencies of living with these patients ${ }^{(6)}$.

In this sense, statements of family members revealed that the objective of the association of promoting a better quality of life of carers and sufferers through support, information and the possibility of sharing experiences has been achieved. These activities enable the discussion and search for a solution to common problems, and allow families to increase their capacity and ability to provide care. Without this support, family members would feel helpless and confused with the perspective of taking care of a sufferer and without hope for a cure.

[...] I came to get help, support and information here at the association meetings. It was here that I started to understand lots of things. They gave me lots of support, and they really helped a lot. (Dahlia-mother)

$[\ldots .$.$] I see that, at the association, family support comes$ first. I go to the meetings and see that the people who seek help are being very well attended. (Chrysanthemum-grandfather)

A study on the burden of families who live with sufferers of mental disorders ${ }^{(14)}$, showed the importance of families in the support groups so they can get information on behaviour, symptomatology and treatment of the illness, and receive orientations on the use of psychotropic drugs and their side effects. This study also emphasized the importance of home visits as a strategy for healthcare professionals to get to know the family's reality, and subsequently provide the right orientations, allowing families to feel more confident and capable of acting correctly in relation to symptoms presented by the person with mental suffering ${ }^{(14)}$.

This would imply having a new care logic for people with mental disorders, one in which the family is not merely included in the care plan, but also included in the focus of care. Acknowledging the importance of families in mental health care leads to the creation of actions that allow families to actually provide care. This, however, implies assistance based on the needs of each family, considering its uniqueness and reality ${ }^{(15)}$, which is still distant from our reality.

[...] For the family, there is no assistance! If it weren't for the association, there would be no direct guidelines for families. [...] But, a guided programme from doctors or even from the government, I don't see anything that guided! (Begonia-mother)

[...]Only the people at the association give us any guidelines! (Acacia-mother)

[...] Only the people at the association tell us how to take care of my brother. During the consultations, they don't tell us anything. (Hydrangea-sister)

It could be possible that the actual supply of specific guidelines is impaired by the large demand of patients who require care. In the municipality of this study, the wait for a specialized consultation can exceed twelve months because the number of psychiatrist in the public system is small. This hinders participation of these professionals in educational activities, but does not exempt them from the responsibility of providing guidelines on the various aspects of the disease during individual consultations.

In this context marked by assistance-based deficiencies, support groups for family members try to meet the needs of most families who live with sufferers of mental disorders.

Participants of this study stated that the support group was essential to consolidate effective care to people with mental disorders and their families in the paradigm of deinstitutionalization. The only mentioned actions of the mental health network were medical consultations and free 
medication, which reveals care that exclusively focuses on the patient, with a curative approach. Statements showed that, although families deserve attention in the context of deinstitutionalization, they do not get attention and are not even considered during assistance.

In this sense, the RAPS should promote the strengthening of relationships in the social environments and several possibilities of social exchange for people with mental disorders and their family members. These services can favour a sense of being of patients beyond the family or home environment, extended to several social spaces, which can contribute to a rehabilitation and social inclusion process of subjects with mental suffering ${ }^{(16)}$.

\section{Idealized care}

For the participants of this study, approaching the family with appropriate guidelines should be given priority, considering that the lack of orientation is perceived as a huge problem for the family from the moment the disease is diagnosed.

[...] people find out they have a person with a mental disease in their families and the doctors should offer some orientation, training, a meeting, to specifically train the family, to explain the disease, to refer patients. It has to be direct so families can become aware of the real situation of the sufferer. (Acacia-father)

The importance of differentiated and singular follow-up was also mentioned.

[...] I think that the ideal support is visiting the family. That is differentiated care. They could even call to know what the situation at home is. That's useful to not lose that link with the patient. It's not just a matter of going there and that's it. Psychotherapy and that's it. They should dedicate a little more time and attention to the case. (Daisy-father)

Obviously, knowing the situation in which the family is inserted allows care that recognizes the possibilities and needs of each member and enables them to confront the situation and adapt their lives in relation to the disorder ${ }^{(17)}$.

In this context, nurses who acknowledge the characteristics of people with mental disorders and their families can provide care that is closer to their needs, using a wide range of intervention instruments, such as: listening, empathy, reception, bonding, shared responsibility and support array (integration of different knowledge areas in all levels of care). This way, it is possible to build a singular therapeutic project with intervention proposals to provide specific care for each individual, resulting in the effective establishment of a care network ${ }^{(4)}$ that can meet the demands and needs mentioned by the families, and reduce unnecessary referrals and waiting time for specialized consultations.

For the family, which is the foundation of human relationships, the fact of having a member with a mental disorder causes, on both sides, a critical experience that profoundly affects the lives of everyone that is directly involved. Consequently, healthcare professionals should reflect on their interventions with these patients and their family members and identify their real needs ${ }^{(18)}$, mentioned by Fuchsia-grandfather and Acacia-father, who even proposed strengthening the support group as a way to extend the network of substitute services.

[...] when you go there for the consultation, I am always with him and say how he's doing, but I don't get any orientations on the treatment. They just tell me not to miss the appointment. (Fuchsia-grandfather)

[...] if you have a family member with a mental disorder, the consultation and the medication are not enough [...]family awareness is also necessary. But there isn't any of that, yet. The healthcare professional has to be trained to create that awareness and orient the family. (Acacia-father)

It should be noted that when talking about expectations, Tulip-sister suggested a service that already exists in the mental health care network and is offered at the CAPS, which reveals a lack of knowledge on available services, the probable deficiency in communication between network services, and the lack of orientation on behalf of healthcare professionals.

[...] it's tough to get, but there should be a service that offers lots of activities for the sufferer [...]. That would be great. (Tulip-sister)

Psychiatric internment was mentioned as a service that, albeit necessary and effective in certain situations, disintegrates the family bond. Jasmine-son and Hydrangea-sister showed they knew the importance of sufferers being with the family to improve prognosis of the disease.

[...] I think that psychiatric internment wouldn't be a good option, because he loses that bond with his family, 
he stays there for a long time and then seems distant at home. (Jasmine-son)

[...] when he comes back, after being interned, he's apprehensive and loses that intimacy. He must think we do it to punish him. (Hydrangea-sister)

People with mental disorders should not be separated from the family context and, considering its relevance, the family should be a resource to promote comfort and for the patient to acquire confidence and consequently invest in his or her recovery ${ }^{(18)}$.

In the model of psychosocial rehabilitation, the purpose of treatment is to increase patient autonomy. For this reason, the family institution is perceived as fundamental and family involvement is considered extremely beneficial ${ }^{(19)}$. This model consequently promotes treatment in which the family is valued, orientated and effectively participates in the promoted actions.

\section{IFINAL CONSIDERATION}

The conception of family members who participated in this study on the performance of self-help groups is positive because they represent a location where they find support and help to take better care of their family member with a mental disorder. Participants also perceived the lack of preparation of many healthcare professionals in relation to providing guidelines and even of managing mental health cases. The need for information and orientations was mentioned as one of the factors that make the self-help group essential for frequenters, as they manage to compensate the lack of assistance of healthcare professionals, who do not provide the desirable or necessary support.

It should be noted that even the fact that there were not many participants in the self-help groups was interpreted as being the result of a lack of knowledge and information on the services offered by the association, and of deficiencies in communication of healthcare professionals with families and within the actual mental health care services network.

It is believed that interventions that seek to favour the physical and mental health of the family members of patients with mental disorders, especially those who share the daily care routine, are very important because they closely confront adversities and burdens of the disease and its treatment. These interventions, however, need to be the focus of investigations so that their results can promote their improvement and simultaneously favour their incorporation in the daily routines of care practices.
Expectations related to care for people with mental disorders are thought to be a concrete contribution of the study insofar as they target possible paths and strategies to be used for this purpose. The conduction of new studies on a larger and more diversified number of individuals is suggested, considering that the number of participants and the fact that they were all from the same support groups were the limitations of this study.

\section{REFERENCES}

1. Brischiliari A, Waidman MAP. 0 portador de transtorno mental e a vida em família. Esc Anna Nery Rev Enferm. 2012;16(1):147-56.

2. Bessa JB, Waidman MAP. Família da pessoa com transtorno mental e suas necessidades na assistência psiquiátrica. Texto Contexto Enferm. 2013;22(1):6170.

3. Quinderé PHD, Jorge MSB, Nogueira MSL, da Costa LFA, Vasconcelos MGF. Acessibilidade e resolubilidade da assistência em saúde mental: a experiência do apoio matricial. Cienc Saude Colet. 2013;18(7):2157-66.

4. Ministério da Saúde (BR). Secretaria de Atenção à Saúde. Departamento de Atenção Básica. Saúde mental. Brasília; 2013. 176 p. Cadernos de Atenção Básica, n. 34 .

5. Ministério da Saúde (BR). Portaria № 3.088, de 23 de dezembro de 2011. Institui a Rede de Atenção Psicossocial para pessoas com sofrimento ou transtorno mental e com necessidades decorrentes do uso de crack, álcool e outras drogas, no âmbito do SUS [Internet] 2011. [cited 2014 jun 27]. Available in: http://bvsms.saude.gov.br/bvs/saudelegis/gm/2011/ prt3088_23_12_2011_rep.html.

6. Scardoelli MGC, Waidman MAP. "Grupo" de artesanato: espaço favorável à promoção da saúde mental. Esc Anna Nery Rev Enferm. 2011;15(2):291-9.

7. Schopler JH, Galinsk MJ. Support groups as open systems: a model for practice and research. Health Soc Work. 1993;18(3):195-207.

8. Dias VP, Silveira DT, Witt RR. Educação em saúde: 0 trabalho de grupos em atenção primária. Rev APS. 2009;12(2): 221-7.

9. Lima HP, Braga VAB, Fernandes AFC, Alves e Souza AM, Marinho AM. Interfaces entre alcoolismo e promoção da saúde nas produções da pós-graduação stricto sensu brasileira. Rev Rene. 2010;11(4):190-9.

10. Martins RV, Rossetto M, Sartori QDN, Pinto EC, Van Der Sand ICP, Hildebrandt LM. Ações de saúde mental na região norte do Rio Grande do Sul, Brasil. Rev Gaúcha Enferm. 2012;33(1):11-8.

11. Bardin L. Análise de conteúdo. Lisboa: Edições 70; 2008.

12. Cordeiro FR, Terra MG, Piexak DR, Ely GZ, de Freitas FF, Silva AA. Cuidados de enfermagem à pessoa com esquizofrenia: revisão integrativa. Rev Enferm UFSM. 2012;2(1):174-81.

13. Caçapava JR, Colvero LA. Estratégias de atendimento em saúde mental nas unidades básicas de saúde. Rev Gaúcha Enferm. 2008;29(4):573-80.

14. Borba, LO, Schwartz E, Kantorski LP. A sobrecarga da família que convive com a realidade do transtorno mental. Acta Paul Enferm. 2008;21(4):588-94.

15. Waidman MAP, Radovanovic CAT, Scardoelli MGC, Estevam MC, Pini JS, Brischiliari A. Estratégia de cuidado a famílias de portadores de transtornos mentais: experiências de um grupo de pesquisa. Cienc Cuid Saude. 2009;8(supl.):97-103.

16. Nasi C, Schneider J. Social relationships in the quotidian of users of a psychosocial care center: a phenomenological study. OBJN [Internet] 2010 Apr [cited 
$2011 \mathrm{fev} 21$ 1;9(1). Available in: Social relationships in the quotidian of users of a psychosocial care center: a phenomenological study

17. Costa B, Inoue L, Kohiyama VY, Paiano M, Waidman MAP. Assistência de enfermagem domiciliar à família e portadores de transtorno mental: relato de experiência. Cogitare Enferm. 2010;15(2):354-8.
18. Navarini V, Hirdes A. A família do portador de transtorno mental: identificando recursos adaptativos. Texto Contexto Enferm. 2008;17(4):680-8.

19. Jorge MSB, Ramirez ARA, Lopes CHAF, Queiroz MVO, Bastos VB. Representações sociais das famílias e dos usuários sobre participação no tratamento de pessoas com transtorno mental. Rev Esc Enferm USP. 2008;42(1):135-42.
Author's address:

Adriano Brischiliari

Rua Tietê, 222, ap. 202, Zona Sete

87020-210, Maringá, PR

E-mail: adriano.enfermeiro@hotmail.com
Received: 06.07.2013

Approved: 08.08.2014 